\title{
Canadian International Polar Year (2007-2008): an introduction
}

\author{
T. Kulkarni • J. M. Watkins • S. Nickels • D. S. Lemmen
}

Received: 1 August 2012 / Accepted: 27 August 2012

(C) Her Majesty the Queen in Right of Canada as represented by: Aboriginal Affairs and Northern Development Canada 2012

\begin{abstract}
Canadian contributions to International Polar Year (IPY) 2007-2008 were designed to improve the understanding of climate change impacts and adaptation and to gain insight into issues surrounding community health and well-being in Canada's arctic. Fifty-two research projects, involving scientists, northern partners and communities, focused on the arctic atmosphere and climate, cryosphere, oceans, sea ice, marine ecosystems, terrestrial ecosystems, wildlife as well as human health and community well-being. Key research findings on these topics are presented in this special issue of Climatic Change. This introductory paper presents an overview of the international and Canadian IPY programs and a summary of Canadian IPY results, including progress made in data management and capacity building. The legacy of IPY in Canada includes expanded international scientific cooperation, meaningful partnerships with northern communities, and more northern residents with research training.
\end{abstract}

\section{Introduction}

Organized by the World Meteorological Organization and the International Council for Science, International Polar Year (IPY) involved research in the Arctic and Antarctic to deepen understanding of polar processes and their global linkages. The official 24 month

Electronic supplementary material The online version of this article (doi:10.1007/s10584-012-0583-5) contains supplementary material, which is available to authorized users.

T. Kulkarni $(\bowtie)$

Northern Policy and Science Integration Branch, Aboriginal Affairs and Northern Development Canada, Ottawa, Ontario, Canada

e-mail: tanuja.kulkarni@aandc-aadnc.gc.ca

J. M. Watkins

Oceanography and Climate Branch, Department of Fisheries and Oceans, Ottawa, Ontario, Canada

S. Nickels

Inuit Qaujisarvingat: The Inuit Knowledge Centre, Inuit Tapiriit Kanatami, Ottawa, Ontario, Canada

D. S. Lemmen

Climate Change Impacts and Adaptation Division, Natural Resources Canada, Ottawa, Ontario, Canada 
observing period, from March 2007 to February 2009, represented the fourth such international initiative, with previous Polar Years having been held in 1882-1883, 1932-1933, and 1957-1958. The 2007-2008 international IPY program examined a wide range of physical, biological and social research topics involving 62 countries, more than 200 international research networks, and thousands of researchers.

Canada was one of several countries that played strong roles in the development and delivery of the international IPY program. Canadian priorities included placing emphasis on the human dimension of polar regions, representing an important expansion of the scope of previous IPYs which focused almost exclusively on the physical sciences (Bulkeley 2010). Canada's 2007-2008 IPY science activities focused on two overarching themes: climate change impacts and adaptation, and the health and well-being of northern communities. The Government of Canada, through many departments, granting councils and research foundations, supported research, logistical services, training, capacity building, communication and outreach, and data management for IPY over a period of 6 years. Many others, including territorial governments, First Nations and Inuit organizations, made significant contributions to the design and delivery of Canadian IPY activities. In total, Canada hosted over 1900 researchers, 240 of whom were international collaborators from 23 countries, as well as the final international IPY conference in Montreal in April, 2012.

\subsection{Past International Polar Years}

During the previous three IPYs, scientists from around the world undertook intensive scientific and exploration programs in polar regions. They set the stage for many international scientific collaborations as well as a long-standing political accord, the Antarctic Treaty (Scientific Committee on Antarctic Research 2012).

The first IPY (1882-1883) was motivated by the understanding that the answers to many fundamental questions of meteorology and geophysics were likely to be found near the earth's poles, but that the scale of investment needed could only be achieved through international cooperation (Barr and Ludecke 2010). In total, 11 nations participated in 15 expeditions to the poles: 13 to the Arctic, and two to the Antarctic. Fourteen Arctic research stations were set up, three of them in Canada. Data and observations amassed over the course of that year would form the basis for much of our understanding of the Earth's magnetic field and climate (Krupnik et al. 2011). The first IPY set an important precedent for international science cooperation. The decision to coordinate, rather than compete, with other nations in polar regions and to focus on scientific endeavours was a bold approach that left a lasting example for future generations to follow.

In 1932-1933, the second IPY was launched, having been proposed and promoted by the International Meteorological Organization to investigate the global implications of the newly discovered atmospheric jet stream. Participation by 40 nations, together with the use of the airplane, motorized sea and land transport and new instruments, allowed for an ambitious research agenda (Barr and Ludecke 2010). Detailed observations and experiments made advances in meteorology, magnetism, and atmospheric science. Forty observation stations were established in the Arctic, many of which are still active today (Canadian Polar Commission 2012).

The third IPY, 1957-1958, coincided with the International Geophysical Year (IGY) and applied technology developed during the Second World War, particularly rockets and radar, to scientific research in the upper atmosphere. IGY ushered in the space age with the launch of the world's first satellites. In addition to scientific breakthroughs, a noteworthy political outcome of the IGY was the ratification of the Antarctic Treaty in 1961, which dedicated the continent to peaceful research (Krupnik et al. 2011). 


\section{The Canadian International Polar Year 2007-2008 Program}

For the purpose of Canadian IPY 2007-2008 activities, the Canadian arctic region includes all of the area north of the southern limit of discontinuous permafrost (Fig. 1). Areas within the region share many common biogeographic characteristics, but also have distinctive environmental, socioeconomic, cultural and political landscapes. Population densities are very low throughout the region. Outside of regional centres, most Arctic communities are exemplified by small (less than 500 people), young and growing populations. Infrastructure is limited, with standards of housing, health care, and educational achievement levels falling well below national norms. Arctic communities have a high proportion of Aboriginal residents, with levels of unemployment and underemployment of Aboriginals exceeding those of non-aboriginal residents (Bone 2012). While local economies tend to be small and underdeveloped, there is significant resource wealth (renewable and non-renewable) and development potential.

Traditional cultural practices, including maintenance of oral traditions and continued dependence on country foods, remain the foundation of many Arctic communities. Because of this, the collective knowledge of Canadian Aboriginal people was a central pillar of Canada's IPY activities, and efforts were made to combine standard scientific approaches with traditional and community-based knowledge to bring new perspectives to understanding the changing physical, natural and social environment (Carlson 2010). As witnesses to the impacts of climate change, the knowledge of northerners on wildlife resources, transportation, sea ice, marine ecosystems, and changing cryospheric conditions was applied in many IPY projects and has significantly contributed to a better understanding of the economic, social, cultural, health and well-being of Arctic inhabitants.

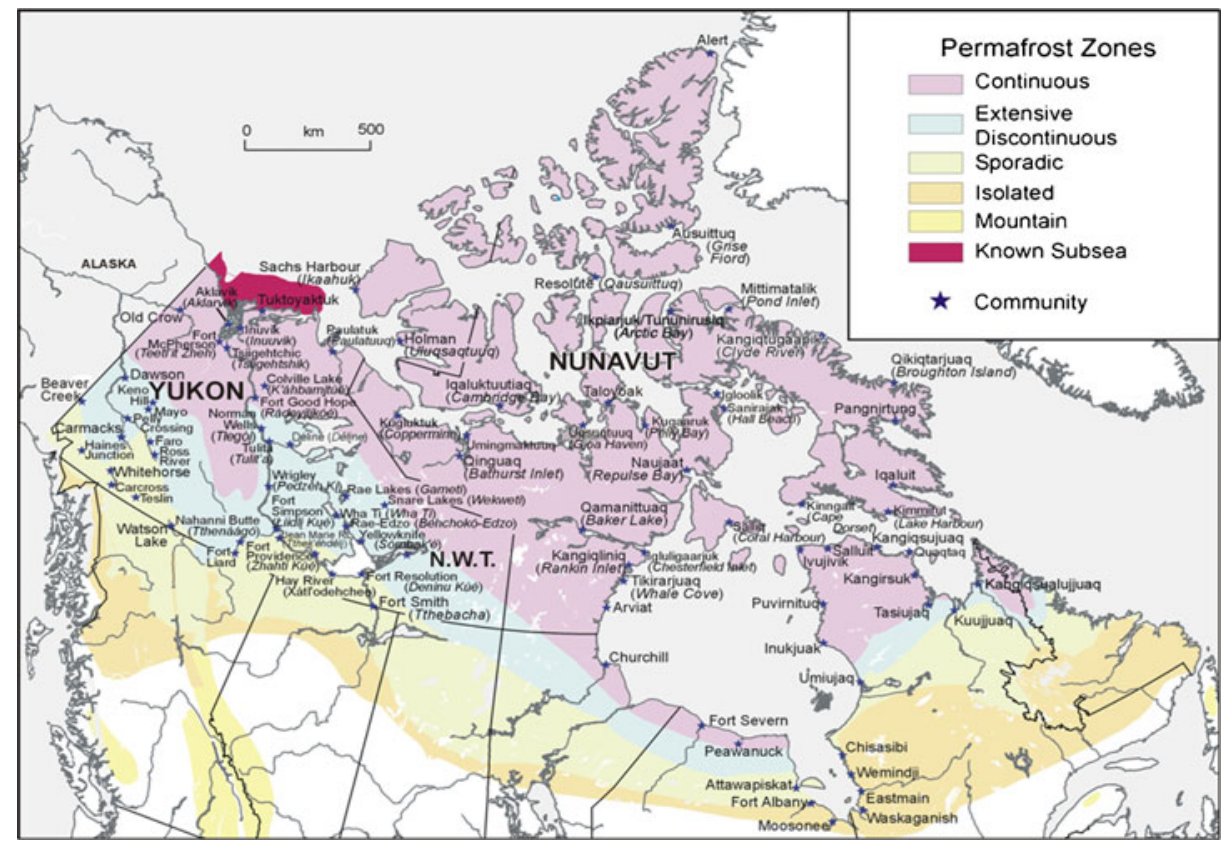

Fig. 1 Map of Canada highlighting areas north of the southern limit of discontinuous permafrost (Lemmen et al. 2008) 
The climate of the Arctic has shown an unprecedented rate of change during the past 50 years, and the Canadian Arctic has experienced significant increases in temperature and precipitation, consistent with other circumpolar regions, including temperature increases twice the global average (Anisimov et al. 2007). All global climate models project a continuation of these changes across the Canadian Arctic, with the greatest increases occurring at high latitudes (Arctic Monitoring and Assessment Programme 2011). There is evidence that the changes in climate are affecting ecological, economic and human systems, and some individuals, communities, and institutions are already taking action to reduce or adapt to these impacts (Aboriginal Affairs and Northern Development Canada 2010).

In the context of the two overarching themes of the Canadian IPY, climate change impacts and adaptation, and the health and well-being of northern communities, efforts were made to facilitate interdisciplinary research that includes traditional knowledge, to develop the next generation of polar scientists, to engage and support the involvement of northerners in all aspects of IPY research, and to increase the awareness among all Canadians of the issues facing the Arctic. The investment of $\$ 156 \mathrm{M}$ of new funds represents the largest single investment the Government of Canada has made in northern science, and was among the highest investments of all participating nations. This funding supported 52 research projects (Table 1) and 212 sub-projects (Government of Canada 2011). The full list of projects endorsed by the international IPY program can be found in the Supplementary Electronic Information (Fig. SM1).

Ancillary components of the Canadian investment in IPY related to ensuring the health and safety of researchers and northern communities during IPY, and enhancing northern research infrastructure to meet researchers' needs. Health and safety initiatives included improving emergency preparedness through training of 200 volunteers in search and rescue, improved communication and navigation equipment, establishment of remote site command posts and fuel caches, and improved dissemination of sea ice information and modelling outputs. With respect to infrastructure, because a number of the research facilities built during the last IPY (1957-1958) were in need of upgrading (Beaulieu et al. 2008), improvements were made to 18 research stations located across Canada's North. Stations offered year-round logistical support, including air and land transportation, communications, field equipment, accommodation and expert advice; all of which assisted to support the increasing demand for northern research within Canada and internationally (Government of Canada 2012b).

Another important aspect of logistics was support for Northern Coordination Offices in the Yukon, NWT, Nunavut and Nunavik. These offices served as points of contact for researchers coming North, facilitated engagement of northern residents, set up regional reviews of project proposals, organized and delivered workshops, and communicated IPY science within each region (Government of Canada 2012c). Additionally, 13 projects provided education and training opportunities for youth and northerners and encouraged them to participate in northern scientific research. Each science project was required to involve students and develop northerners' skills by, for example, hiring and training field assistants, guides, and monitors (Government of Canada 2011).

Finally, data and information management was a critical aspect of the Canadian IPY and its legacy. All principal investigators funded through the Government of Canada were required to make all project data available (Government of Canada 2012d). Six Canadian data centres / research libraries were established to form the IPY Data Assembly Centre Network, which preserves and provides access to IPY observations, with metadata stored in the Polar Data Catalogue at the University of Waterloo (Canadian Cryospheric Information Network 2012). Further, all bibliographic information about Canadian publications emerging from IPY are being compiled by the IPY Publications Database at the Arctic Institute of 
Table 1 Canadian IPY Projects and Affiliation of Principal Investigator (Government of Canada 2012a)

Project Title

Affiliation of Principal

Investigator

Sea Ice and Oceans

The Circumpolar Flaw Lead System Study

University of Manitoba

Ocean Production of Trace Gases in the Arctic and their Impact on Climate Université Laval

The Carbon Cycle in the Canadian Arctic and Sub-Arctic Continental Margin Université du Quebec

Impacts of Severe Arctic Storms and Climate Change on Coastal Areas

Investigation of the Effect of Climate Change on Nutrient and Carbon

Cycles in the Arctic Ocean

Ocean Currents of Arctic Canada

Fisheries and Oceans Canada

University of British Columbia

C3O - Canada's Three Oceans

Fisheries and Oceans Canada

Fisheries and Oceans Canada

Natural Climate Variability and Forcings in Canadian Arctic and Arctic Oceans

Hydrology/Cryosphere

Measuring the Impact of Climate Change on Landscape and Water Systems in the High Arctic

Variability and Change in the Canadian Cryosphere (Snow and Ice)

Arctic Freshwater Systems

Environmental Change in the High Arctic from Snow and Ice Cores

Permafrost Conditions and Climate Change

Atmosphere

Arctic Weather and Environmental Prediction Initiative

The PEARL near the Pole-Atmospheric Research in the High Arctic

OASIS-CANADA: Understanding Ozone and Mercury in the Air

Over the Arctic Ocean

Pollutants Travelling in the Air to the Arctic

Understanding the Dehydration-Greenhouse Feedback Process in the Arctic

Structure and Evolution of the Polar Atmosphere

Université du Québec à Rimouski

Queen's University

Environment Canada

Environment Canada

Natural Resources Canada

University of Ottawa

Environment Canada

University of Toronto

Environment Canada

Environment Canada

Université du Québec à Montréal

University of Toronto

Ecosystems

Impacts of a Changing Arctic Tree Line

Dalhousie University

Climate Change Impacts on Canadian Arctic Tundra

The Impact of Climate Change on Tundra Wildlife

University of British Columbia

Université Laval

Polar Research Observatories for Biodiversity and the Environment (PROBE)

Climate and Alpine Tundra Ecosystems in Southwest Yukon

University of Guelph

Dynamic Response of Arctic Glaciers to Global Warming

University of Alberta

University of Alberta

Microbial Biodiversity of High Arctic Ecosystems (MERGE)

Carbon Cycle

Carbon, Microbial and Plant Community Dynamics in Low-Arctic Tundra

Changing Forests and Peatlands Along the Mackenzie Valley

Université Laval

Wildlife

Polar Ecosystems in Transition: An Interdisciplinary Investigation into the Impacts of Climate Change on Polar Bears

How Seabirds Can Help Detect Ecosystem Change in the Arctic

Beluga Tagging in the Arctic

Climate Variability and Change Effects on Chars in the Arctic

University of British Columbia

Natural Resources Canada

Government of Nunavut

Memorial University

Fisheries and Oceans Canada

Fisheries and Oceans Canada 
Table 1 (continued)

\begin{tabular}{|c|c|}
\hline Project Title & $\begin{array}{l}\text { Affiliation of Principal } \\
\text { Investigator }\end{array}$ \\
\hline Determining the Diet of the Greenland Shark in a Changing Arctic & University of Windsor \\
\hline Effects of Global Warming on Polar Bears, Seals and Whales & Fisheries and Oceans Canada \\
\hline $\begin{array}{l}\text { Monitoring the Impacts of Global Change on Caribou and Wild } \\
\text { Reindeer and their Link to Human Communities }\end{array}$ & Yukon College \\
\hline $\begin{array}{l}\text { Environmental Change and Traditional Use in the Old Crow Flats in } \\
\text { Northern Canada }\end{array}$ & Vuntut Gwitch'in First Nation \\
\hline \multicolumn{2}{|l|}{ Community Well-being } \\
\hline \multirow[t]{2}{*}{ Northwest Territories Ice Patch Study } & Prince of Wales Northern \\
\hline & Heritage Centre \\
\hline Inuit Sea Ice Use and Occupancy Project & Carleton University \\
\hline Inuit History: Climatic Change and Historical Connections in Arctic Canada & $\begin{array}{l}\text { Canadian Museum of } \\
\text { Civilization }\end{array}$ \\
\hline Constructed Wetlands for Treatment of Wastewater in Arctic Communities & Fleming College \\
\hline Dynamic Inuit Societies in Arctic History & University of Toronto \\
\hline Engaging Communities in the Monitoring of Country Food Safety & Makivik Corporation \\
\hline Communities in the Changing Arctic & University of Guelph \\
\hline The Impacts of Oil and Gas Activity on Peoples in the Arctic & York University \\
\hline $\begin{array}{l}\text { Kwaday Dan Ts'inchi Discovery-Expanding our Understanding } \\
\text { through Linked Scientific and Community Studies Project }\end{array}$ & $\begin{array}{l}\text { Champagne and Aishihik } \\
\text { First Nations }\end{array}$ \\
\hline $\begin{array}{l}\text { Traditional Knowledge and Climate Change in Tr'ondëk Hwëch'in } \\
\text { Traditional Territory }\end{array}$ & Trondek Hwech'en \\
\hline \multicolumn{2}{|l|}{ Human Health } \\
\hline $\begin{array}{l}\text { Evaluating the Effectiveness of Vaccination Against Respiratory } \\
\text { Infections for Young Children of the Nunavik Region }\end{array}$ & Université Laval \\
\hline Coordinated Effort to Clear Hepatitis Viruses from the Canadian North & University of Manitoba \\
\hline Human Papillomavirus and Cervical Disease in the Northwest Territories & $\begin{array}{l}\text { Public Health Agency } \\
\text { of Canada }\end{array}$ \\
\hline An Integrated Research Program on Arctic Marine Fat and Lipids & $\begin{array}{l}\text { Centre Hospitalier de } \\
\text { l’Université Laval }\end{array}$ \\
\hline Inuit Health Survey: Inuit Health in Transition and Resiliency & McGill University \\
\hline Arctic Peoples, Culture, Resilience and Caribou & Council of Yukon First Nations \\
\hline
\end{tabular}

North America. Over 4000 publications have been added to the IPY publications database to date, and publishing of IPY research results will continue for several more years.

\section{Special Issue on Canadian results from IPY 2007-2008}

This Special Issue of Climatic Change presents synthesis papers on several interrelated topics covered by the Canadian IPY program: community well-being, arctic atmosphere and climate, cryosphere, oceans, sea ice, marine ecosystems, terrestrial ecosystems, wildlife and human health. The interdisciplinary nature of these themes, and the central role of community health and well-being, is illustrated in Fig. 2. Approximately half of the projects discussed in this Special Issue had a traditional knowledge component, on topics such as 


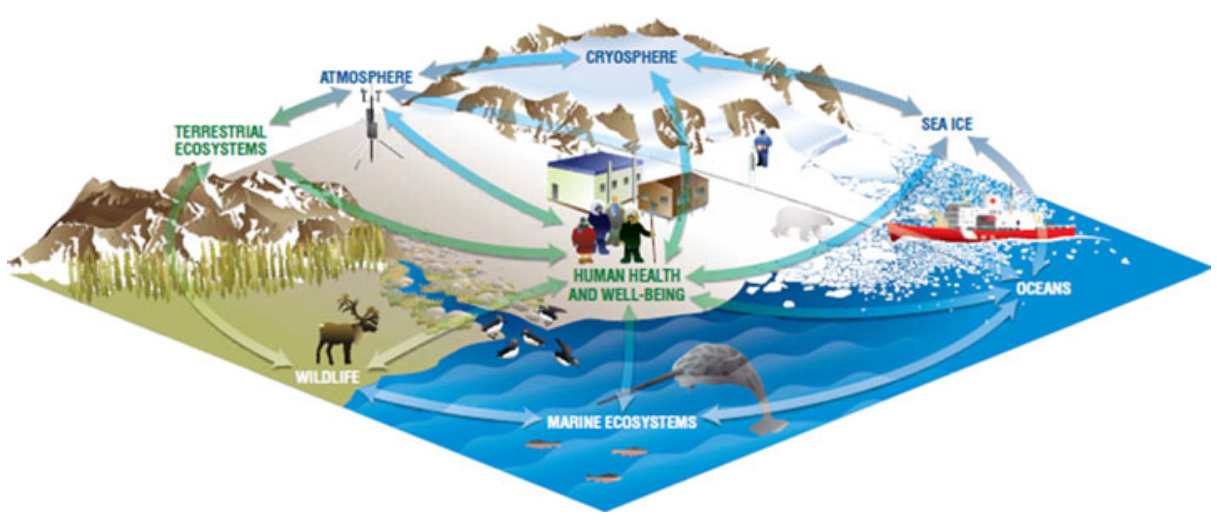

Fig. 2 Relationships between the themes of the IPY special issue papers

country food nutrition and changes in sea ice conditions, and the associated impacts on northern communities. Traditional knowledge was collected by local researchers, translators and interpreters in communities during exchanges with elders, hunters and trappers, teachers, nurses and other community representatives.

\subsection{Community well-being (Parlee and Furgal 2012)}

The well-being of northerners is a growing focus of national and international interest, building on a long history of collaborative social science research in the arctic. This paper outlines key social science concepts studied in Canadian IPY projects, including vulnerability, adaptation, resilience and security in the context of environmental change. Results include details on community stresses, with the greatest environmental concern stemming from climate change and resource development. The value of traditional knowledge is described as a critical guide for adaptation and resilience of northerners to changing environmental conditions, as well as key to understanding well-being in the arctic. Changing land use patterns, food security, and community engagement and governance are reviewed as components to well-being, and presented with potential adaptation options to manage climate-related risks. Residents of arctic communities are responding to physical environmental changes as well as to cultural shifts. Collaboration and engagement of northern organizations and communities in science, it is hoped, will be a lasting legacy of Canada's IPY program. IPY research has demonstrated how different systems of knowledge can combine to produce a richer understanding of the arctic.

\subsection{Arctic atmosphere and climate (Perrie et al. 2012)}

Several Canadian IPY projects addressed Arctic atmosphere, ocean, ice and land interfaces using high accuracy measuring methods and computer modeling. Highlights of the analysis include that decreased sea ice contributes to more intense storms, higher winds, reduced surface albedo, increase surface air temperature and enhanced vertical mixing. Another key finding has implications for human health — a warming arctic may remobilize persistent organic pollutants and increase the retention and deposition of mercury in the environment. Changes in sea ice can affect ozone, bromine oxide, and mercury processes that occur at the surface of the ice as well as the properties of the atmosphere. This paper discusses the tracking and transport of pollution and smoke plumes from mid-latitudes to the northern pole as it describes the structure and properties of the arctic atmosphere. 


\subsection{Cryosphere (Derksen et al. 2012)}

Through its influence on the surface energy balance of the Earth and on moisture and gas fluxes within the Earth system, the polar cryosphere plays an important role in Arctic and global climate, ocean circulation, freshwater hydrology, and terrestrial and marine ecosystems. This paper, which presents a synthesis of IPY research on the Canadian polar cryosphere, is among the first to describe consistent pan arctic warming based on observational data. The IPY period marked an acceleration of historic trends, including permafrost warming, reduction of snow cover extent, increased glacier mass loss, reduction of summer sea ice extent, and thinning and break-up of the Canadian ice shelves. These changes have important implications for regional transportation and infrastructure.

\subsection{Oceans (Melling et al. 2012)}

Ocean variability and change are the twin themes of this paper, which describes how IPY projects on oceans contribute to the conceptual framework of the arctic climate system, and how Canadian work fits into the international understanding of the Arctic Ocean. Specifically, the paper considers work done in oceanography, air-sea interactions, ocean storm response, paleoclimate, and the geochemistry of trace elements. Unprecedented conditions in the Beaufort Sea were observed and documented, and the paper describes a recent reversal of the mid-depth Arctic Ocean circulation. New techniques in tracking sediment were applied, and linked to Arctic Oscillation. The role of wind is repeatedly discovered to be a potent agent of change in the marine Arctic, and the role of ice cover is also described to be of critical importance. This paper outlines the first completed description of Canadian arctic through-flow.

\subsection{Sea ice (Barber et al. 2012a, Barber et al. 2012b)}

There are two papers dedicated to sea ice, focused on the causes of change and variability, and the consequences of change and variability of sea ice. Sea ice-themed research in this IPY represented the most diverse international science program and facilitated the exchange of Inuit knowledge and scientific ideas across nations and disciplines. The cultural exchanges were important in explaining and communicating the transformation of the Arctic ecosystem to a seasonally ice-free state. The first paper summarizes the basin-wide and regional sea ice trends and links them to Inuit knowledge of sea ice, and considers the causes of the observed changes. Longer open water areas, summer sea ice decay linked to wave action, the role of cyclones in flaw leads and feedbacks related to increased open water are described. The second paper describes the change and variability of the timing and magnitude of sea ice, and the impacts that the thermodynamic state has on marine ecosystems. Primary productivity, marine mammal habitats and sea ice as storage and transport of contaminants are discussed. The Circumpolar Flaw Lead Systems Study was the largest project in IPY nationally and internationally. New information from that work includes; tracking nutrient cycling from the Pacific Ocean to arctic surface waters, preferences for ringed seal and polar bear habitat, high biological productivity of flaw lead importance for beluga habitat and the extreme activity of climate active gases in sea ice environments.

\subsection{Marine ecosystems (Tremblay et al. 2012, Darnis et al. 2012)}

Major components of marine ecosystems were assessed and the current state and changing trends were determined. The projects had a wide range, and considered most regions of the 
Canadian Arctic and the coastal and offshore areas of the Beaufort Sea. The results of the IPY projects have considerably improved our understanding of the responses of marine ecosystems to climate warming and how the productivity and structure of the food web may impact the ecosystem services, including food supply, provided to northerners. Marine ecosystem project results are synthesized in two papers, the first targeting primary production. This paper includes a discussion on the potentially substantial bottom up effects of offshore warming and freshening of the surface layer, the role of wind on primary production and its impacts as sea ice retreats, and the new finding of primary production activity that had not been detected remotely. The second paper centers on secondary production, and includes several significant findings, including; that major food web components showed relatively high level of winter activity, indicating that the system may be more resilient to an increasingly variable arctic climate than was known prior to this IPY initiative. The arctic marine biodiversity is comparable to that of the Canadian Pacific and Atlantic coasts, which contrasts another widely held model of the region. Decreased summer ice cover has allowed more killer whales to use the Arctic for hunting, and they will likely emerge as the new apex predator in the region.

\subsection{Terrestrial ecosystems (Henry et al. 2012)}

The temperature gradients of the Arctic mean that plant communities will likely show a quick and strong response to temperature change. Continued rising temperatures will result in abundance and an northern expansion in range of grasses and flowers. Vegetation model projections for the present century indicate that, depending on location, the boreal forest will displace between $11 \%$ and $50 \%$ of all Arctic tundra. These changes will affect other wildlife, result in alterations to the geographic ranges of freshwater species due to loss of optimal habitat for native Arctic species and expand the habitat of more southerly species. The negative impacts on Arctic adapted species will be through changes in food web structure, migration routes, vulnerability to predators, and the arrival of invasive species, including new pathogens, predators and competing species. This paper discusses the IPY projects that were the first to carry out comprehensive assessments of the state and changes of the Canadian northern terrestrial ecosystems and demonstrate through site-specific responses, that these systems are inherently variable. The response of tundra and taiga ecosystems to the past three to five decades of warming was the focus of this paper. Increased shrub density was detected at several scales, and tree growth was correlated to temperature. Seedling establishment was monitored and site specific responses were detected. Resistance to warming was found in plant and soil communities. This paper describes how combining traditional knowledge and science in monitoring ecosystem change can improve our understanding of the arctic system.

\subsection{Wildlife (Ferguson et al. 2012)}

It is important that we understand the state and trends in northern wildlife, as it is an important component to northern culture; from nutrition, to clothing to food security, and can drive northern economies. This paper focuses on the trends in the wildlife populations, and suggests that science drive policy and management decisions. The long term vertebrate index compiled from data over the past 30 years indicates that there has been a continuous decline in population abundance by $30 \%$ since 1990 . Time series analysis shows that the potential value of the timeseries can be used at a variety of scales, and the range of time series described in this paper covers significant wildlife dynamics in the north. Of particular note is the need for consistent data, greater spatial range and integration of circumpolar observations. 
Better understanding the health of northern communities was an important part of Canada's IPY research. The Inuit Health Survey was the largest health focused project in IPY, surveying 36 communities and creating a baseline for human health in the north founded on data from adult and child surveys. This enumeration of northern community health will net circumpolar statistics that have already informed decision making and policies on northern health. Six IPY projects are synthesized to describe the health indicators from Inuit Nunangat. Two critical determinants of health are housing and food. Food security is discussed, including the transition from traditional foods to market foods, and its impact on northern health. Respiratory disease is also discussed as a significant public health issue, particularly for youth. Important gaps in knowledge on human papillomavirus and Hepatitus B are investigated, and risks to northerners are outlined.

\section{Conclusion}

IPY represented a milestone in Arctic research both in Canada and globally. Engagement of northern residents, using local and traditional knowledge and sharing information are now entrenched as standard practices in northern research. Improving contacts and organizational networks among Canadian and international scientists are major successes of IPY. Research results generated through the Canadian IPY activities are already contributing to policy and program development - moving from research to action.

\section{References}

Aboriginal Affairs and Northern Development Canada (AANDC), 2010. Sharing Knowledge for a Better Future: Adaptation and clean energy experiences in a changing climate. $31 \mathrm{pp}$.

Arctic Monitoring and Assessment Programme (AMAP), 2011. Climate Change in the Arctic - a hot topic!, from SWIPA 2011: Snow, Water, Ice and Permafrost in the Arctic. 18p. ISBN: 978-82-7971-072-1

Anisimov OA, Vaughan DG, Callaghan TV, Furgal C, Marchant CH (2007) Polar regions (Arctic and Antarctic). Climate Change 2007: Impacts, Adaptation and Vulnerability. In: Parry ML (ed) Contribution of Working Group II to the Fourth Assessment Report of the Intergovernmental Panel on Climate Change. Cambridge University Press, Cambridge, pp 653-685

Barber DG, Asplin MG, Raddatz R, Candlish L, et al. (2012). Causes of change and variability in sea ice during the 2007-2008 Canadian IPY program. Clim Change (this issue)

Barber DG, Asplin MG, Papakyirakou T, Miller L, et al. (2012). Concequences of change and variability in sea ice during the 2007-2008 Canadian IPY program. Clim Change (this issue)

Barr S, Ludecke C (eds) (2010) The History of the International Polar Years (IPYs). Springer, Berlin. ISBN 978-3-642-12402-0

Beaulieu, JM, Bennett J, Bigras S, (2008) Canadian Polar Commission. Beacons of the North: Research Infrastructure in Canada's Arctic and Subarctic. 55p

Bone RM (2012) The Canadian North: Issues and Challenges, 4th Edition, Oxford University Press, 344 pp.

Bulkeley R (2010) Ther Frist Three Polar Years - A general overview. In The History of the International Polar Years (IPYS), Springer, Barr, Ludecke (eds.)

Canadian Polar Commission (CPC) (2012) Northern Research Facilities. http://www.polarcom.gc.ca/ index.php?page=northern-research-facilities\&hl=en_US Accessed July 24, 2012.

Carlson D (2010) Why do we have a 4th IPY? In The History of the International Polar Years (IPYS), Springer, Barr, Ludecke (eds.)

Canadian Cryospheric Information Network (2012) Polar Data Catalogue. http://www.polardata.ca/ Accessed, July 24, 2012. 
Darnis G, Robert D, Pomerleau C, Link H, et al. (2012) Current state and changing trends in Canadian Arctic marine ecosystems: II. Secondary production, pelagic-benthic coupling and biodiversity. Clim Change (this issue)

Derksen C, Smith SL, Share M, Brown L, et al. (2012) Variability and change in the Canadian cryosphere. Clim Change (this issue)

Ferguson SH, Berteaux D, Gaston AJ, Higdon JW, et al. (2012) Vertebrate time series data for the Canadian arctic: From science to management to policy. Clim Change (this issue)

Government of Canada (2011) Government of Canada Program for International Polar Year: Highlights and Achievements, Ministry of Aboriginal Affairs and Northern Development Canada; 77pp

Government of Canada (2012). International Polar Year: Government of Canada program for IPY. http:// www.api-ipy.gc.ca/pg_IPYAPI_012-eng.html Accessed July 24, 2012.

Government of Canada (2012) International Polar Year: Logistics for health and safety. http://www.apiipy.gc.ca/pg_IPYAPI_060-eng.html Accessed July 24, 2012.

Government of Canada (2012). International Polar Year: IPY Northern Coordination Offices. http://www.apiipy.gc.ca/pg_IPYAPI_063-eng.html. Accessed July 24, 2012.

Government of Canada (2012). International Polar Year: Data management. http://www.api-ipy.gc.ca/pg IPYAPI_052-eng.html Accessed July 24, 2012.

Henry GHR, Bhatti J, Chen W, Deslippe J, et al. (2012) Effects of climate change on terrestrial ecosystems in northern Canada: Results from the International Polar Year (2007-2008). Clim Change (this issue)

Krupnik I, Allison I, Bell R, Cutler P, Hik D, et al. (eds.) (2011) Understanding Earth's Polar Challenges: International Polar Year 2007-2008 Summary by the IPY Joint Committee. University of the Arctic. CCI Press, Edmonton, Alberta and ICSU/WMO Joint Committee for International Polar Year 2007-2008.

Lemmen DS, Warren FJ, Bush E, Lacroix J (eds) (2008) From Impacts to Adaptation: Canada in a Changing Climate 2007. Government of Canada, Ottawa

Melling H, Francois R, Myers PG, Perrie W et al. (2012) The Arctic ocean: A Canadian perspective. Clim Change (this issue)

Owens S, De Wals P, Egeland G, Furgal C, et al. (2012) Global changes and public health in the Canadian Arctic. Clim Change (this issue).

Parlee B, Furgal C, (2012) Well-being in the Arctic: A synthesis of selected research from Canada's International Polar Year program. Clim Change (this issue)

Perrie W, Long Z, Hung H, Cole A, et al. (2012) Selected topics in arctic atmosphere and climate. Clim Change (this issue)

Scientific Committee on Antarctic Research (SCAR) 2012. The Antarctic Treaty System: an introduction. www.scar.org/treaty/ Accessed August 20, 2012.

Tremblay, JE, Robert, D, Varela, DE, Lovejoy C, et al. (2012) Current state and changing trends in Canadian arctic marine ecosystems: I. Primary Production. Clim Change (this issue) 